\title{
Coronary Aneurysms in the Setting of Kawasaki Disease with Two Different Evolutions
}

\author{
Éden Santos P*, Correia-Costa A, Gonçalves E, Moura C, Moreira J and João Baptista M \\ Department of Pediatric Cardiology, Centro Hospitalar de São João, Portugal
}

Submission: June 20, 2018; Published: August 21, 2018

*Corresponding author: Paulo Éden Santos, Centro Hospitalar de São João. Alameda Prof. Hernâni Monteiro, 4200-319, Porto, Portugal, Tel: 00351910914664; Email: edenforever@live.com.pt

\section{Introduction}

Luis Garrido-García et al. [1] reported the incidence of giant coronary aneurysms during the acute phase of Kawasaki disease was $8.1 \%$, higher than that reported in studies from countries with a high prevalence of the disease. In $88.2 \%$ of the patients with giant coronary aneurysms, the diagnosis was made after 10 days of the onset of fever, and the longer duration of symptoms until diagnosis and treatment seems to be related to the development of giant coronary aneurysms $(\mathrm{p}<0.000)$. Despite the importance of giant coronary artery aneurysms, there are a few studies evaluating risk factors for their development. In 2010, Sudo et al described risk factors for developing giant coronary aneurysms and found that being younger than 1 year or older than 5 years, receiving a total dose of immunoglobulin $>2500 \mathrm{mg} / \mathrm{kg}$, and the use of corticosteroids following the administration of intravenous immunoglobulin were risk factors for giant coronary aneurysms.

Nakamura et al. [2] reported that being younger than 1 year, having leucocytosis, having a low serum concentration of sodium, as well as having low haemoglobin and elevated alanine aminotransferase levels were risk factors for the development of giant coronary aneurysms.

A 16-years-old female, with no relevant pathological history, diagnosed with Kawasaki disease at age 3, an echocardiogram revealed coronary aneurysms on the $15^{\text {th }}$ day of illness, intravenous immunoglobulin and acetylsalicylic acid was initiated. She was discharged after 34 days, referred to our outpatient clinics for the follow-up. Selective coronary angiography showed aneurysms of the anterior descending artery with $12 \times 7 \mathrm{~mm}$ diameter $(\mathrm{Z}$ score of $>10$ ), calcification of the middle segment of the right coronary artery, with $10 \mathrm{~mm}$ maximum diameter. Despite coronary lesions, she is asymptomatic, medicated with acetylsalicylic acid and warfarin. The treadmill test and scintigraphy showed no signs of coronary thrombosis or ischemia.

Male, with irrelevant pathological antecedents, diagnosed with atypical Kawasaki disease at 5 years-old, complicated with respiratory insufficiency, bilateral effusion, generalized edema, uveitis. Even with incomplete characteristics for Kawasaki disease started intravenous immunoglobulin and acetylsalicylic acid. At the $14^{\text {th }}$ day of the disease, the echocardiogram showed the origin of the left coronary with $4.5 \mathrm{~mm}$ diameter ( $\mathrm{Z}$ score of $>4.3$ ), common trunk with $5 \mathrm{~mm}$ ( $\mathrm{Z}$ score of $>7.4$ ), anterior descending with $5 \mathrm{~mm}$ (Z score of $>6.6$ ), an aneurysm with $7 \mathrm{~mm}$ of maximum diameter. Diffuse dilation of the right coronary artery with a diameter of $5 \mathrm{~mm}$. Initiated hypocoagulation with warfarin and maintained acetylsalicylic acid, and was discharged after the completion of the therapeutics. He's now 6 years-old, clinically well, and cardiac catheterization showed complete regression of a coronary aneurysm and he suspended warfarin but remains with acetylsalicylic acid in antiaggregant dose.

Our patients had coronary aneurysms, some of the most serious complications of Kawasaki disease. Although rare, the occurrence of these aneurysms is important as their presence affects the prognosis of the disease [3]. The aetiology of Kawasaki disease remains unknown and it is not possible to establish strategies to prevent it. Therefore, efforts must focus on determining the risk factors for the development of the most serious outcomes in order to decrease morbidity and mortality in these patients. Thrombus can easily develop in the coronary aneurysms despite strict anticoagulant therapy and coronary arteries may be occluded suddenly [4]. Acute myocardial infarction can occur and is mainly caused by a fresh thrombus.

Treatment with corticosteroids, immunoglobulins and acetylsalicylic acid may reduce the incidence of cardiac complications in Kawasaki disease. Even though the disease has been continuously reported, the clinical features of Kawasaki disease in terms of cardiovascular surgical aspects were not sufficiently discussed. Percutaneous transluminal coronary angioplasty is indicated for localized severe stenotic lesions. Considering that our first patient remains asymptomatic regardless of the fact that having the coronary aneurysms, we suggested that these patients must have a close follow-up and a very aggressive anticoagulation therapy with multiple agents. Surgical intervention (e.g, coronary artery 
bypass) should be recommended for patients who have ischemic changes with multivessel disease in spite of maximal medical therapy [5].

\section{Funding}

No funding has supported this work.

\section{Competing Interests}

No competing interests associated with any of the authors.

\section{Ethical standards}

This article does not include any studies with human participants performed by any of the authors.

\section{References}

1. Garrido-García LM, Morán-Villaseñor E, Yamazaki-Nakashimada MA, Cravioto P, Galván F (2017) Giant coronary artery aneurysms complicating Kawasaki disease in Mexican children. Cardiol Young 28(3): 386-390.

2. Yosikazu N, Mayumi Y, Ritei U, Makoto W, Morihiro T, et al. (2003) Casecontrol study of giant coronary aneurysms due to Kawasaki disease. Pediatr Int 45(4): 410-413.

3. Sudo D, Monobe Y, Yashiro M, Sadakane A, Uehara R, et al. (2010) Casecontrol study of giant coronary aneurysms due to Kawasaki disease: the 19th nationwide survey. Pediatr Int 52(5): 790-794.

4. Nabuchi A, Sonobe T (2001) Minimally invasive coronary artery bypass grafting surgery in a child with Kawasaki disease. Jpn J Thorac Cardiovasc Surg 49(1): 82-84.

5. McCrindle BW, Rowley AH, Newburger JW, Burns JC, Bolger AF, et al. (2017) Diagnosis, Treatment, and Long-Term Management of Kawasaki Disease: A Scientific Statement for Health Professionals From the American Heart Association. Circulation135(17) : e927-e999.

Your next submission with Juniper Publishers will reach you the below assets

- Quality Editorial service

- Swift Peer Review

- Reprints availability

- E-prints Service

- Manuscript Podcast for convenient understanding

- Global attainment for your research

- Manuscript accessibility in different formats ( Pdf, E-pub, Full Text, Audio)

- Unceasing customer service

Track the below URL for one-step submission https://juniperpublishers.com/online-submission.php 